\title{
Effects of meteorological variables on sugarcane ripening in the Cauca river valley, Colombia ${ }^{1}$
}

\author{
Carlos Andrés Unigarro Muñoz ${ }^{2}$, Fernando de Jesús Villegas Trujillo ${ }^{3}$
}

\section{ABSTRACT}

Sugarcane ripening is conditioned by the interaction between biological factors of the crop and climate. This study aimed to evaluate the effects of some meteorological variables on the sucrose content, during the ripening period, in the Cauca river valley (Colombia). The evaluations were conducted at seven locations, during four periods, being each one a threemonth period. The meteorological variables of maximum, mean and minimum air temperature, diurnal vapor pressure deficit and precipitation were evaluated with respect to the sucrose variable (\% cane). The results showed that a low precipitation and a high vapor pressure deficit increased the sucrose content in the stems. High minimum temperatures during the maturation stage decreased the sucrose levels, although their effect was less noticeable than previously mentioned. The meteorological conditions in the different localities caused substantial differences in the sucrose concentration of the stems, especially during the beginning of the maturation phase. However, these differences were reduced by the age of the crop and by the periods of rainfall or drought occurrence.

KEYWORDS: Sucrose, vapor pressure deficit, minimum temperature.

\section{INTRODUCTION}

The sugar-alcohol sector of Colombia is composed of 13 sugar mills located in the geographical valley of the Cauca river, between the latitudes $3^{\circ}$ and $5^{\circ} \mathrm{N}$ and longitudes $75^{\circ} 49^{\prime}$ and $76^{\circ} 35^{\prime} \mathrm{W}$. In 2019, the area that was planted with sugarcane (Saccharum spp.) for the production of sugar and ethanol measured 241,205 hectares, of which 200,499 hectares were harvested with a mean age of 12.8 months and a mean of 5.2 cuts (Cenicaña 2020). The commercial sucrose content presented

\section{RESUMO}

Efeitos de variáveis meteorológicas no amadurecimento de cana-de-açúcar no vale do rio Cauca, Colômbia

O amadurecimento da cana-de-açúcar é condicionado pela interação entre os fatores biológicos da cultura e o clima. Objetivou-se avaliar os efeitos de algumas variáveis meteorológicas sobre o teor de sacarose, durante o período de maturação, no vale do rio Cauca (Colômbia). As avaliações foram realizadas em sete localidades, durante quatro períodos, cada um com duração de três meses. As variáveis meteorológicas de temperatura máxima, média e mínima do ar, déficit de pressão de vapor diurno e precipitação foram avaliadas em relação à variável sacarose (\% cana). Os resultados mostraram que uma baixa precipitação e um alto déficit de pressão de vapor aumentaram o teor de sacarose nos colmos. Altas temperaturas mínimas durante a maturação diminuíram os níveis de sacarose, embora seu efeito fosse menos perceptível do que o mencionado anteriormente. As condições meteorológicas nas diferentes localidades causaram diferenças substanciais na concentração de sacarose dos colmos, principalmente durante o início da fase de maturação. No entanto, essas diferenças foram reduzidas pela idade da colheita e pelos períodos de ocorrência de chuvas ou secas.

PALAVRAS-CHAVE: Sacarose, déficit de pressão de vapor, temperatura mínima.

a value of $11.2 \%$, which had an impact on the mean sugar tons produced per hectare $\left(12.5 \mathrm{t} \mathrm{ha}^{-1}\right)$ (Cenicaña 2020). Important advances in the research and development of new technologies have supported this sector, though many aspects, such as the ripening process of sugarcane, remain to be studied in a greater depth.

The sugarcane ripening is regulated by the interaction between the most influential cultivar characteristics and meteorological variables (Cardozo et al. 2014). From a physiological point of view, maturity is not synonymous with ripening. Sugarcane

1. Received: Oct. 18, 2019. Accepted: Apr. 03, 2020. Published: May 06, 2020. DOI: 10.1590/1983-40632020v5060815.

2. Centro Nacional de Investigaciones de Café, Manizales, Caldas, Colombia. E-mail/ORCID: andresunigarro@gmail.com/0000-0002-7344-3211.

3. Centro de Investigación de la Caña de Azúcar de Colombia, Cali, Valle del Cauca, Colombia. E-mail/ORCID: fvillegas@cenicana.org/0000-0002-9425-695X. 
can be easily ripened within a few months after germination, if it is subjected to water, thermal or nutrient stress; however, maturity, age and ripening are closely linked under natural conditions (Cardozo \& Sentelhas 2013). Precipitation determines the amount of sucrose accumulated at the moment of harvesting, but different soil types can store water in different proportions, what may affect the sugarcane ripening (Cardozo et al. 2015). On the other hand, air temperatures and water deficits are effective ripening agents, because they reduce the moisture of the sugarcane stalk (Araújo et al. 2016). For van Heerden (2014), there is an inverse relation between the sucrose concentrations in cane and the minimum mean air temperature. Knowledge of the effects of meteorological variables on the sugarcane ripening is of great importance, because it enables a better scheduling of harvests, in order to take advantage of times when conditions are favorable, thereby resulting in high economic returns. It also minimizes negative effects when conditions are unfavorable (López-Milán \& Plà-Aragonés 2014).

In Colombia, the sugarcane agro-industrial sector has studied the importance of meteorological variables for the sucrose content during ripening (Villegas 2010), although the current production goals demand that this knowledge be refined to obtain higher returns. Therefore, this study aimed to evaluate the effect of certain meteorological variables on the sugarcane sucrose content, during the ripening period, in the Cauca river valley.

\section{MATERIAL AND METHODS}

The data used in this study were obtained from 28 sampling sites, in seven localities of interest distributed throughout the Cauca river valley (Colombia), which were selected for their contrasting soil and climatic characteristics. They were located near the sugar mills of Risaralda (localities of Viterbo and Cartago), Sancarlos (Tulua), Manuelita (Piedemonte and Centro valley) and Incauca (Corinto and Villarrica).

The evaluation took place from September 2011 to December 2012 and was divided into four periods, each with a duration of approximately 3 months, corresponding to the ripening stage of the crop. The crops evaluated during the first and second periods were sampled between 10 and 13 months of age, because the typical harvest time for the sugarcane was approximately 13.9 months. In the third and fourth periods, the crops were sampled between 9 and 12 months of age, because of the decrease in the harvest time selected by the agro-industrial sector for sugarcane. Ripening was monitored in the sugarcane (Saccharum spp.) variety CC 85-92. Other parameters, such as the crop age, harvest date and number of cuts, were kept as similar as possible between the sites to allow for comparisons.

The sampling for sucrose content was performed biweekly at each site. Ten stems were cut at $30 \mathrm{~m}$ from the beginning of the row, to avoid edge effects. The cuts were replicated in four randomized rows, for a total of 40 stems. The stems were transferred to the the laboratory, where the sucrose (\% cane) content, expressed on a fresh weight basis, was determined (Larrahondo \& Torres 1989). Sucrose (\% cane) is a variable comparable to the commercial sucrose $(\%)$ obtained in sugar mills. The commercial sucrose percentage of the sugarcane agro-industrial sector was obtained from databases supplied by the sugar mills.

The meteorological data were obtained from the automated meteorological network of the sugarcane agro-industrial sector and the pluviometers closest to the evaluation sites. The maximum, mean and minimum air temperature, as well as the diurnal vapor pressure deficit, were averaged by the period based on hourly records. The vapor pressure deficit was indirectly estimated from the temperature and relative humidity data registered between 06:00 a.m. and 6:00 p.m. (Allen 2006). In the case of pluvial precipitation, the records were accumulated. Due to the important effect of precipitation on sucrose concentrations (Villegas 2010), the localities were classified into two groups: "semidry", when the rainfall of the evaluated period was lower than the mean for the same period; and "humid", when it was higher.

The experiment used data collected from a survey and evaluated the seven localities by period. The data were subjected to Kruskal-Wallis tests, and the periods and localities were compared using the Fisher's least significant difference method, at a significance of $95 \%$. The results were expressed as mean \pm standard error. The correlations between the commercial sucrose percentage and the maximum, mean and minimum air temperature, as well as the vapor pressure deficit, were assessed using the Pearson's correlation test. All the statistical 
procedures were performed using the statistical package "Agricolae" (Mendiburu 2020) of the R software v. 3.6.0 (R Development Core Team 2019).

\section{RESULTS AND DISCUSSION}

The behavior of the variable sucrose ( $\%$ cane) throughout the evaluated periods influenced the variation in the commercial sucrose pattern, in the Cauca river valley (Figure 1). The commercial sucrose values were usually higher at the end of periods of low precipitation (August and September) and lower at the end of periods of high precipitation (April and May, November and December). In the Cauca river valley, these variations in commercial sucrose have been described by Cock et al. (1993). In this context, sucrose ( $\%$ cane) by age shows a similar trend as that of commercial sucrose, though the sampling ages varied between 10 and 13 months, or between 9 and 12 months, depending on the period (Figure 1). Donaldson et al. (2008) found that the seasonal effect is very important in the accumulation of sucrose in South Africa, and that the season (time of the year) is one of the most important factors. According to Moore et al. (1997), the sucrose content in the stems is dynamic due to seasonal influences and the time, duration and ripening age, in temperate zones. This is because the sucrose ( $\%$ cane) content is expressed in relation to the fresh weight, which may vary throughout the seasons due to changes in the relative water content in the plant or to daytime stomatal activity (Liu \& Helyar 2003, Gilbert et al. 2006), which is dependent on the vapor pressure deficit.

Figure 2 shows that the variations in the maximum air temperature and vapor pressure deficit were positive and highly correlated $(r>0.70)$ with the variation in commercial sucrose, in the Cauca river valley, during 2011 and 2012. The mean air temperature was positive and moderately correlated with the variation in commercial sucrose. From the previous results, the vapor pressure deficit presented the best performance, because it is related to the photosynthesis of the plant (van Dillewijn 1952) and to the water deficit that the stems experience when losing water in the form of vapor, due to transpiration (Gilbert et al. 2006). The vapor pressure deficit is the result of the interaction between radiation and relative humidity (Allen 2006) and also has a very high and positive correlation with the temperature, which depends directly on the solar brightness. The minimum air temperature showed a negative and moderate correlation with the commercial sucrose. In addition, in the months when the minimum air temperature was lower than $18.5^{\circ} \mathrm{C}$, an increase was observed for the commercial sucrose (Figure 2). Glover (1971) suggested that, for the ripening process to begin, the mean air temperature must be lower

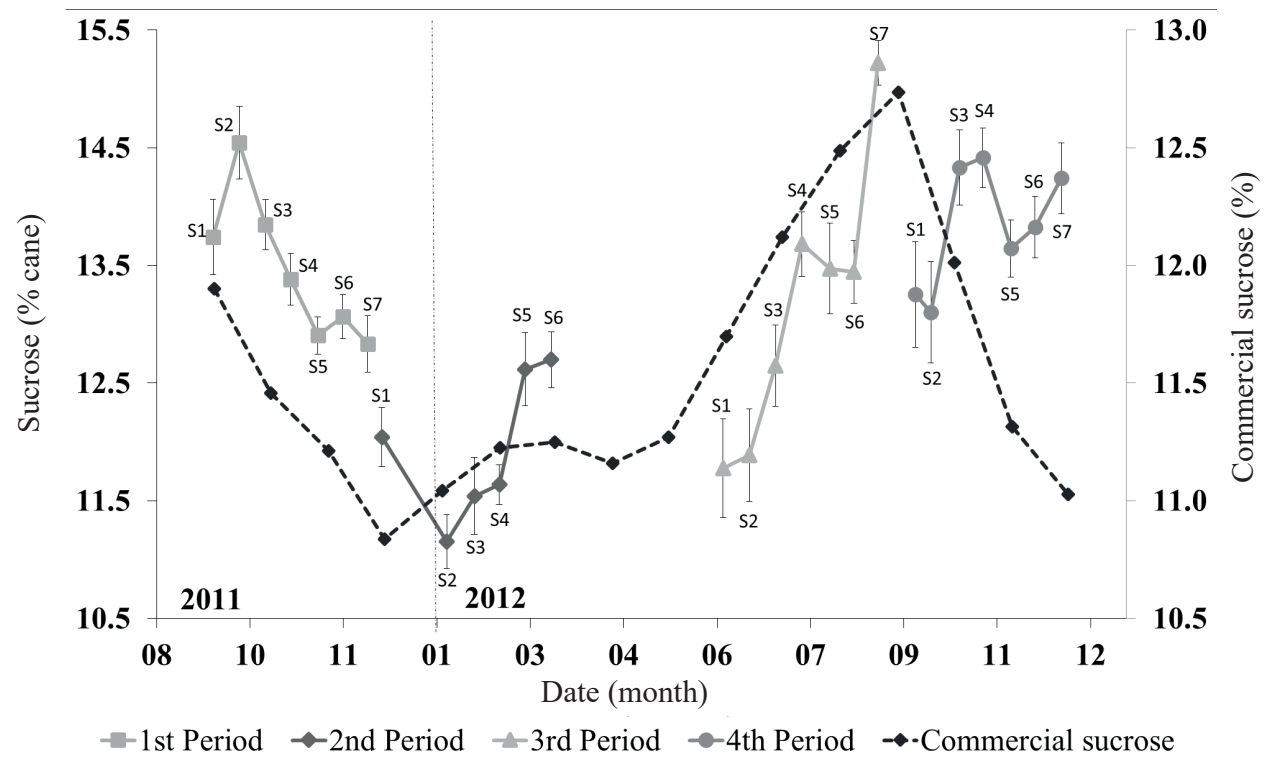

Figure 1. Sucrose (\% cane) and commercial sucrose (\%) in the Cauca river valley (Colombia), during four evaluation periods (September 2011 to December 2012). S\#: sampling number. Vertical bars denote the standard error. 
than $21{ }^{\circ} \mathrm{C}$ for three months. The low temperatures at night reduce the plant growth, which increases the concentration of sucrose in the stems (Scarpari \& Beauclair 2004).

Table 1 shows that, during the first period (September to December 2011), the localities with precipitation lower than the general mean $(545 \mathrm{~mm})$, such as Centro valley and Piedemonte ("semidry"), showed a sucrose ( $\%$ cane) content higher than those at Villarrica and Viterbo, where the rainfall was the highest ("humid"), except for Cartago and Corinto. According to Villegas (2010), the plant sucrose consumption is greater with a greater rainfall, due to the higher availability of moisture in the soil, which causes an increase in the stem growth rate. In the Centro valley and Piedemonte locations, where precipitation was low and the vapor pressure deficit was high, the accumulation of sucrose (\% cane)

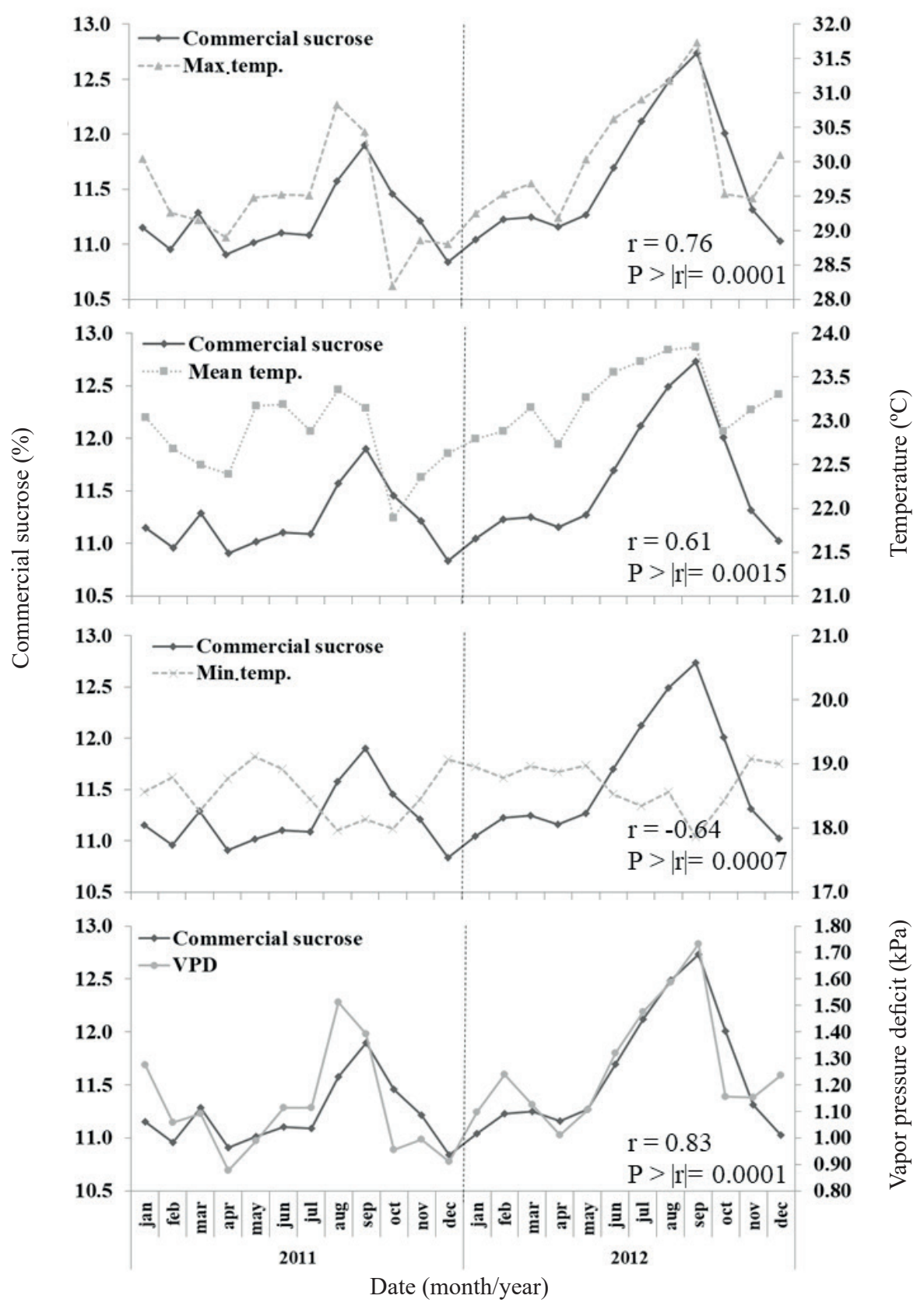

Figure 2. Commercial sucrose (\%), maximum air temperature (Max. temp.), mean air temperature (Mean temp.), minimum air temperature (Min. temp.) and diurnal vapor pressure deficit (VPD) by month, during 2011 and 2012, in the Cauca river valley (Colombia). The Pearson's correlations between the variables and commercial sucrose (\%) are displayed. 
Table 1. Precipitation (PR), vapor pressure deficit (VPD), minimum temperature (Min. temp.) and sucrose (\% cane) during different evaluation periods, in seven localities of the Cauca river valley (Colombia).

\begin{tabular}{|c|c|c|c|c|}
\hline Locality & $\mathrm{PR}(\mathrm{mm})^{1}$ & $\mathrm{VPD}(\mathrm{kPa})^{2}$ & Min. temp. $\left({ }^{\circ} \mathrm{C}\right)^{2}$ & Sucrose $(\% \text { cane })^{2}$ \\
\hline \multicolumn{5}{|c|}{ 1st period (September to December 2011) } \\
\hline Cartago & 566 & $0.76 \pm 0.014 \mathrm{c}$ & $18.4 \pm 0.13 \mathrm{c}$ & $14.2 \pm 0.21 \mathrm{a}$ \\
\hline Centro valley & 207 & $1.06 \pm 0.023 \mathrm{a}$ & $19.1 \pm 0.10 \mathrm{ab}$ & $13.8 \pm 0.37 \mathrm{ab}$ \\
\hline Corinto & 831 & $0.82 \pm 0.024 \mathrm{c}$ & $18.4 \pm 0.12 \mathrm{c}$ & $13.7 \pm 0.22 \mathrm{a}$ \\
\hline Piedemonte & 365 & $1.12 \pm 0.027 \mathrm{a}$ & $19.0 \pm 0.11 \mathrm{~b}$ & $14.1 \pm 0.32 \mathrm{a}$ \\
\hline Tuluá & 410 & $0.92 \pm 0.017 \mathrm{~b}$ & $18.6 \pm 0.12 \mathrm{c}$ & $13.1 \pm 0.17 \mathrm{bc}$ \\
\hline Villarica & 582 & $1.10 \pm 0.031 \mathrm{a}$ & $19.4 \pm 0.12 \mathrm{a}$ & $12.7 \pm 0.18 \mathrm{c}$ \\
\hline Viterbo & 856 & $0.95 \pm 0.022 b$ & $18.4 \pm 0.10 \mathrm{c}$ & $12.9 \pm 0.20 \mathrm{c}$ \\
\hline \multicolumn{5}{|c|}{ 2nd period (December 2011 to March 2012) } \\
\hline Cartago & 427 & $0.96 \pm 0.018 \mathrm{~d}$ & $19.0 \pm 0.06 \mathrm{bc}$ & $11.9 \pm 0.35 \mathrm{ab}$ \\
\hline Centro valley & 491 & $1.10 \pm 0.019 \mathrm{~b}$ & $19.5 \pm 0.08 \mathrm{a}$ & $12.2 \pm 0.27 \mathrm{ab}$ \\
\hline Corinto & 698 & $0.80 \pm 0.015 \mathrm{e}$ & $18.9 \pm 0.06 \mathrm{c}$ & $12.2 \pm 0.34 \mathrm{ab}$ \\
\hline Piedemonte & 492 & $1.17 \pm 0.021 \mathrm{a}$ & $19.5 \pm 0.05 \mathrm{a}$ & $11.4 \pm 0.31 \mathrm{~b}$ \\
\hline Tuluá & 579 & $0.99 \pm 0.020 \mathrm{~cd}$ & $19.2 \pm 0.05 \mathrm{~b}$ & $12.5 \pm 0.30 \mathrm{a}$ \\
\hline Villarica & 633 & $1.20 \pm 0.020 \mathrm{a}$ & $19.7 \pm 0.10 \mathrm{a}$ & $11.5 \pm 0.34 \mathrm{ab}$ \\
\hline Viterbo & 849 & $1.04 \pm 0.019 \mathrm{c}$ & $18.9 \pm 0.12 \mathrm{bc}$ & $11.8 \pm 0.32 \mathrm{ab}$ \\
\hline \multicolumn{5}{|c|}{ 3rd period (May to September 2012) } \\
\hline Cartago & 163 & $1.61 \pm 0.044 \mathrm{a}$ & $19.1 \pm 0.07 \mathrm{a}$ & $12.3 \pm 0.49 \mathrm{c}$ \\
\hline Centro valley & 180 & $1.48 \pm 0.022 \mathrm{~b}$ & $19.1 \pm 0.05 \mathrm{a}$ & $14.5 \pm 0.25 \mathrm{a}$ \\
\hline Corinto & 187 & $1.25 \pm 0.041 \mathrm{~cd}$ & $19.2 \pm 0.08 \mathrm{a}$ & $14.0 \pm 0.30 \mathrm{ab}$ \\
\hline Piedemonte & 180 & $1.46 \pm 0.024 \mathrm{~b}$ & $19.0 \pm 0.05 \mathrm{a}$ & $13.2 \pm 0.32 \mathrm{bc}$ \\
\hline Tuluá & 143 & $1.23 \pm 0.023 \mathrm{~d}$ & $18.7 \pm 0.08 \mathrm{~b}$ & $13.5 \pm 0.30 \mathrm{bc}$ \\
\hline Villarica & 188 & $1.56 \pm 0.039 \mathrm{ab}$ & $18.7 \pm 0.13 \mathrm{~b}$ & $13.6 \pm 0.43 \mathrm{abc}$ \\
\hline Viterbo & 275 & $1.32 \pm 0.021 \mathrm{c}$ & $18.2 \pm 0.07 \mathrm{c}$ & $12.2 \pm 0.46 \mathrm{c}$ \\
\hline \multicolumn{5}{|c|}{ 4th period (September to December 2012) } \\
\hline Cartago & 371 & $1.14 \pm 0.020 \mathrm{~b}$ & $18.7 \pm 0.06 \mathrm{~d}$ & $13.8 \pm 0.40 \mathrm{c}$ \\
\hline Centro valley & 328 & $1.31 \pm 0.032 \mathrm{a}$ & $19.2 \pm 0.11 \mathrm{~b}$ & $14.8 \pm 0.22 \mathrm{ab}$ \\
\hline Corinto & 267 & $1.08 \pm 0.054 \mathrm{bc}$ & $19.2 \pm 0.12 b$ & $14.2 \pm 0.26 \mathrm{bc}$ \\
\hline Piedemonte & 328 & $1.32 \pm 0.039 \mathrm{a}$ & $19.1 \pm 0.12 b c$ & $15.3 \pm 0.35 \mathrm{a}$ \\
\hline Tuluá & 283 & $1.01 \pm 0.025 \mathrm{c}$ & $19.0 \pm 0.14 \mathrm{~cd}$ & $13.5 \pm 0.27 \mathrm{~cd}$ \\
\hline Villarica & 367 & $1.26 \pm 0.040 \mathrm{a}$ & $19.9 \pm 0.09 \mathrm{a}$ & $13.5 \pm 0.24 \mathrm{~cd}$ \\
\hline Viterbo & 370 & $1.10 \pm 0.009 \mathrm{bc}$ & $18.8 \pm 0.07 \mathrm{~d}$ & $12.9 \pm 0.25 \mathrm{~d}$ \\
\hline
\end{tabular}

${ }^{1}$ Accumulated value; ${ }^{2}$ mean value and standard error. Different letters indicate differences between means according to the LSD test at $95 \%$ of significance.

was higher than that in Viterbo, which showed the opposite conditions (Table 1). Cardozo (2012) mentioned that the ripening process is stimulated when the atmospheric demand for water vapor is high and precipitation is low due to the water stress generated in the plant. In Villarrica, although the vapor pressure deficit was high, the sucrose (\% cane) content was low, because the precipitation was very high (Table 1). According to Alexander (1973), these conditions are propitious for rehydrating the tissues and promoting the inversion of sucrose in the stems. In Cartago, a value of $14.2 \%$ units of sucrose ( $\%$ cane) was reached, possibly due to the low minimum temperature recorded. A decrease in temperature promotes a reduction in acidic invertases and an increase in neutral invertases in the stems, what benefits the sucrose content (Ebrahim et al. 1998).

Figure 3 shows that the differences between localities for sucrose (\% cane) were very marked between 10 and 11 months of age. The excess of precipitation caused a decrease in the sucrose (\% cane) content, despite the increase in the crop age. Gilbert et al. (2006) observed that the production (tons of sucrose per hectare) varied widely among the environments, even when the same crop, growing season, crop age and harvest time were evaluated. Liu \& Helyar (2003) observed that the amount of moisture in the stem and, consequently, that of the sucrose are very dependent on the time and weather conditions.

In the second period (December 2011 to March 2012), the localities classified as "semidry" (Cartago and Centro valley), with precipitation lower than the general mean $(596 \mathrm{~mm})$, did not show a notable difference in the sucrose (\% cane) content, with respect to the "wet" localities (Villarrica, Corinto and Viterbo), where the precipitation was higher. Only Piedemonte was lower than Tulua in sucrose content (Table 1). The sucrose content decreased in all localities during the second period, as compared to the first period (Table 1; Figure 3). 


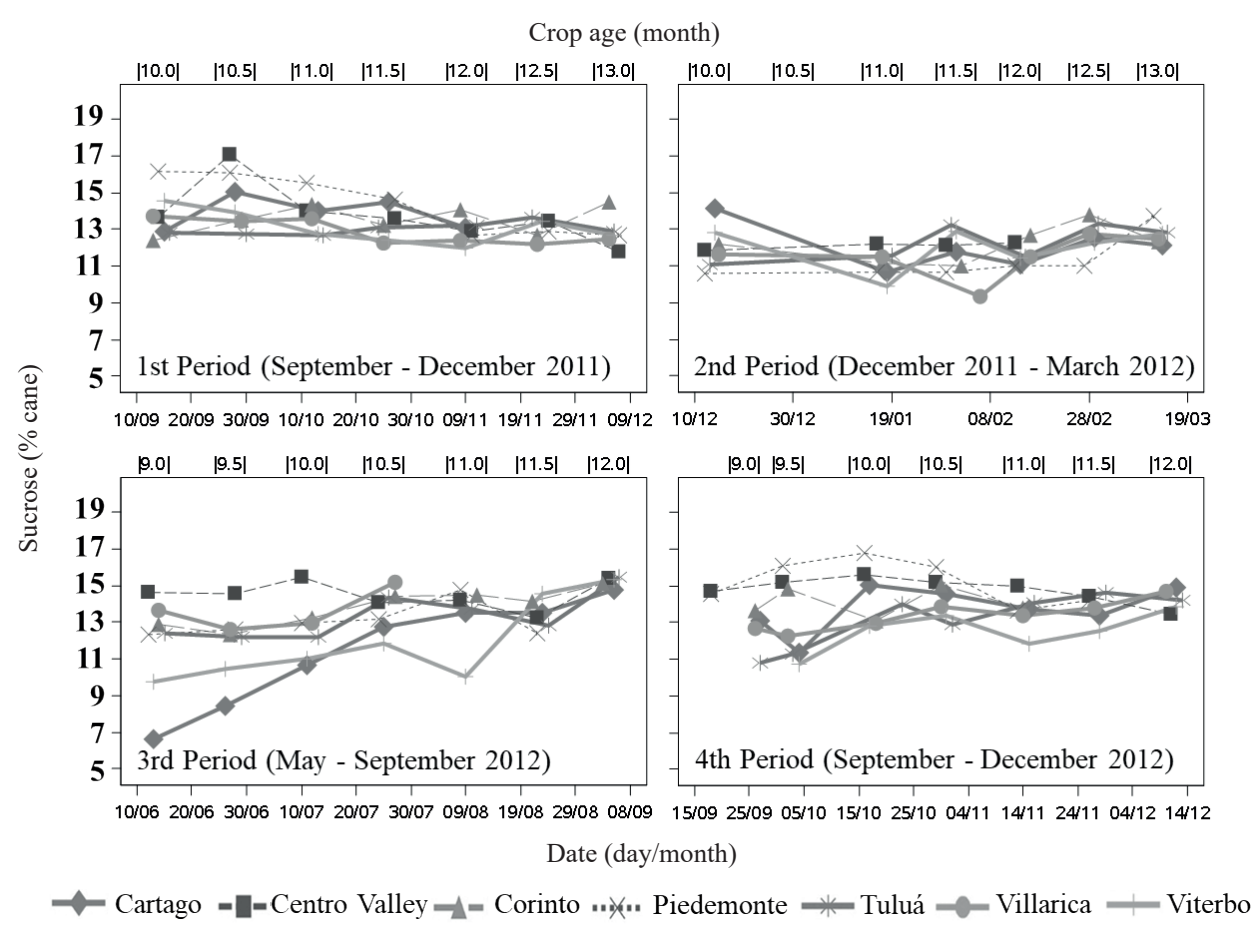

Figure 3. Sucrose (\% cane) in seven locations of the Cauca river valley (Colombia), during four evaluation periods.

The mean minimum temperature was higher in the second period $\left(19.4{ }^{\circ} \mathrm{C}\right)$ than in the first period $\left(18.8^{\circ} \mathrm{C}\right)(\mathrm{p}<0.05)$, because the localities were between $0.4{ }^{\circ} \mathrm{C}$ and $0.7^{\circ} \mathrm{C}$ warmer (Table 1$)$. According to Lingle \& Irvine (1994), the concentration of sucrose in cane crops tends to be lower under conditions of warm periods at night and wet periods during the day, which are more favorable for the vegetative development. In Piedemonte, where the warmer minimum temperatures and the highest vapor pressure deficit were recorded, the lowest sucrose ( $\%$ cane) was also observed. In contrast, Tulua, with a colder minimum temperature and low vapor pressure deficit, presented the highest sucrose (\% cane) content. The vapor pressure deficit in this second period was very similar (between $0.76 \mathrm{kPa}$ and $1.14 \mathrm{kPa}$ ) to that in the first period (between $0.78 \mathrm{kPa}$ and $1.17 \mathrm{kPa})(\mathrm{p}>0.05)$ (Table 1).

The localities of Cartago, Tulua, Centro valley, Piedemonte, Corinto and Villarrica had a "semidry" condition in the third period (May to September 2012), registering precipitations lower than or equal to the general mean $(188 \mathrm{~mm})$. Centro valley and Corinto presented the highest values for sucrose (\% cane) concentration, with respect to Cartago and Viterbo (the latter was the only locality with "humid" conditions in this period) (Table 1). In all localities, the precipitation was between $264 \mathrm{~mm}$ and $574 \mathrm{~mm}$ lower than that in the second period (Table 1). According to Inman-Bamber \& Smith (2005), the water stress during maturation enhances the production of sucrose. The vapor pressure deficit values fluctuated between $1.22 \mathrm{kPa}$ and $1.60 \mathrm{kPa}$ during the third period and were much higher $(\mathrm{p}<0.05)$ than those registered during the second period, which ranged between $0.76 \mathrm{kPa}$ and $1.14 \mathrm{kPa}$ (Table 1). Cardozo (2012) observed that the lower rainfall and higher atmospheric demand for water vapor and lower rainfall reduce the water availability in plants, thus stimulating ripening. These conditions, according to Bakker (1999), are optimal for the accumulation of sucrose in the sugarcane stems. The mean minimum air temperature $\left(18.9^{\circ} \mathrm{C}\right)$ was reduced significantly $(\mathrm{p}<0.05)$ by $0.4{ }^{\circ} \mathrm{C}$, when compared to that obtained during the second period $\left(19.3{ }^{\circ} \mathrm{C}\right)$, which favored the accumulation of sucrose in all localities (Table 1). Cock et al. (1993) mentioned that there is an inverse relationship between sucrose and monthly minimum mean temperature.

Figure 3 shows that the sucrose (\% cane) content was very different among locations (8.5$14.5 \%$ ) at the beginning of the sampling period, but as summer (August-September) continued, the concentrations of sucrose increased until they 
converged on values close to $15 \%$ for all the locations at the last sampling. Julien \& Delaveau (1977) observed that the effect of the environment on the sucrose content was highly significant when expressed on the basis of fresh weight. According to Liu \& Helyar (2003), the progressive decrease in the humidity of the stems due to water deficits increases the sucrose concentration, which is finally stabilized by the low demand on the sink. In Centro valley and Corinto, the sucrose concentration was high at an early age and remained relatively stable over time (Figure 3). Inman-Bamber (1994) reported a high sucrose content in young crops during the summer.

Table 1 shows that, during the fourth period (September to December 2012), the "semidry" localities, such as Centro valley and Piedemonte, with a lower precipitation had higher concentrations of sucrose, when compared to those in Cartago, Tuluá, Villarrica and Viterbo, where precipitation was higher. Compared to the third period, the precipitation increased between $80 \mathrm{~mm}$ and $208 \mathrm{~mm}$ in all localities. This increase in precipitation during the fourth period for the Cauca river valley agrees with that predicted by Cortés \& Barrios (2010). However, the mean sucrose ( $\%$ cane) for the fourth period $(12.1 \%)$ was higher than that registered during the third period $(11.3 \%)(p<0.05)$, what may be explained by the accumulated water deficit between June and September 2012. According to Robertson \& Donaldson (1998), the accumulated water deficit during the months before harvest is an important factor for ripening. The vapor pressure deficit varied between $1.07 \mathrm{kPa}$ and $1.37 \mathrm{kPa}$ during the fourth period, being lower than during the third period $(p<0.05)$, in which the vapor pressure deficit values fluctuated between $1.22 \mathrm{kPa}$ and $1.60 \mathrm{kPa}$. However, in Centro valley and Piedemonte, the high sucrose concentrations resulted from the high vapor pressure deficit and low rainfall (Table 1).

Up to mid-October, the sucrose (\% cane) content in the Piedemonte and Centro valley localities exceeded $15 \%$, despite these canes being approximately 10 months old. This is unlike the sucrose (\% cane) contents in Tulua and Viterbo, which, during the best cases, did not reach $14 \%$. The rains that arrived at the end of October and continued throughout November (data not shown) stimulated the crop growth and caused a decrease in sucrose (between 10.3 and 11.5 months old) for most of the localities, although, after 12 months, the values for sucrose increased again. Frequent drops in the sucrose concentration may be associated with an increased moisture in the stem from precipitation (van Dillewijin 1952).

\section{CONCLUSION}

Sugarcane ripening in the Cauca river valley, measured in terms of sucrose ( $\%$ cane) concentration, is dependent on weather conditions, not solely on the harvest age. The meteorological variables with a higher influence on the sugarcane sucrose content include precipitation, diurnal vapor pressure deficit and minimum air temperature. When precipitation is low, the vapor pressure deficit is high and minimum temperatures are low, what allows high sucrose ( $\%$ cane) values to be obtained at the harvest time. The sucrose content in canes of the same variety may vary considerably between localities, depending on environmental conditions. However, periods of rainfall or drought could decrease the differences between the localities and allow the sucrose to converge to very similar values throughout the Cauca river valley. These results suggest that, in addition to the minimum temperature and precipitation, the diurnal vapor pressure deficit can be taken into account as a variable predictor in harvest scheduling models to obtain a high yield in sucrose.

\section{ACKNOWLEDGMENTS}

This research was funded by the Centro de Investigación de la Caña de Azúcar de Colombia (Cenicaña). The authors are grateful for collaborations with professionals from the Agronomy Program and the Economic and Statistical Analysis Service of Cenicaña.

\section{REFERENCES}

ALEXANDER, A. G. Sugarcane physiology: a comprehensive study of the Saccharum source to sink system. Amsterdam: Elsevier, 1973.

ALLEN, R. G. Evapotranspiración del cultivo: guías para la determinación de los requerimientos de agua de los cultivos. Roma: FAO, 2006.

ARAÚJO, R.; ALVES JUNIOR, J.; CASAROLI, D.; EVANGELISTA, A. W. P. Variation in the sugar yield in response to drying-off of sugarcane before harvest and the occurrence of low air temperatures. Bragantia, v. 75, n. 1, p. 118-127, 2016. 
BAKKER, H. Sugar cane cultivation and management. New York: Springer Science \& Business Media, 1999.

CARDOZO, N. P. Modelagem da maturação da cana-deaçúcar em função de variáveis meteorológicas. 2012. Tese (Mestrado em Ciências) - Escola Superior de Agricultura Luiz de Queiroz, Universidade de São Paulo, Piracicaba, 2012.

CARDOZO, N. P.; SENTELHAS, P. C. Climatic effects on sugarcane ripening under the influence of cultivars and crop age. Scientia Agricola, v. 70, n. 6, p. 449-456, 2013.

CARDOZO, N. P.; SENTELHAS, P. C.; PANOSSO, A. R.; FERRAUDO, A. S. Multivariate analysis of the temporal variability of sugarcane ripening in south-eastern Brazil. Crop and Pasture Science, v. 65, n. 3, p. 300-310, 2014.

CARDOZO, N. P.; SENTELHAS, P. C.; PANOSSO, A. R.; PALHARES, A. L.; IDE, B. Y. Modeling sugarcane ripening as a function of accumulated rainfall in southern Brazil. International Journal of Biometeorology, v. 59, n. 12, p. 1913-1925, 2015.

CENTRO DE INVESTIGACIÓN DE LA CAÑA DE AZÚCAR DE COLOMBIA (Cenicaña). Informe anual 2019. Cali: Cenicaña, 2020.

COCK, J.; LUNA, C. A.; PALMA, A. El clima y el rendimiento en caña de azúcar. Cali: Cenicaña, 1993.

CORTÉS, E.; BARRIOS, C. Búsqueda de señales de cambio climático en el valle del río Cauca. Carta Trimestral - Cenicaña, v. 32, n. 3-4, p. 3, 2010.

DONALDSON, R. A.; REDSHAW, K. A.; RHODES, R.; ANTWERPEN, R. V. Season effects on productivity of some commercial South African sugarcane cultivars: II. Trash production. In: ANNUAL CONGRESS OF THE SOUTH AFRICAN SUGAR TECHNOLOGISTS ASSOCIATION, 81., 2008, Mount Edgecombe. Proceedings... Durban: South African Sugar Technologists Association, 2008. p. 528-538.

EBRAHIM, M. K.; ZINGSHEIM, O.; EL-SHOURBAGY, M. N.; MOORE, P. H.; KOMOR, E. Growth and sugar storage in sugarcane grown at temperatures below and above optimum. Journal of Plant Physiology, v. 153, n. 5-6, p. 593-602, 1998.

GILBERT, R. A.; SHINE JUNIOR, J. M.; MILLER, J. D.; RICE, R. W.; RAINBOLT, C. R. The effect of genotype, environment and time of harvest on sugarcane yields in Florida, USA. Field Crops Research, v. 95, n. 2-3, p. 156170, 2006.

GLOVER, J. Changes in sucrose \% cane and yield of sucrose per unit area associated with cold, drought and ripening. Proceedings of the South African Sugar Technologists Association, v. 46, n. 1, p. 158-164, 1971.

INMAN-BAMBER, N. G. Effect of age and season on components of yield of sugarcane in South Africa.
Proceedings of the South African Sugar Technologists Association, v. 68, n. 1, p 23-27, 1994.

INMAN-BAMBER, N. G.; SMITH, D. M. Water relations in sugarcane and response to water deficits. Field Crops Research, v. 92, n. 2-3, p. 185-202, 2005.

JULIEN, M. H. R.; DELAVEAU, P. The effects of time of harvest on the partitioning of dry matter in three sugarcane varieties grown in contrasting environments. Proceedings of the International Society of Sugar Cane Technologies, v. 16, n. 1, p. 1755-1769, 1977.

LARRAHONDO, A. J.; TORRES, A. J. Evaluación y determinación del azúcar recuperable de la caña de azúcar. Carta trimestral - Cenicaña, v. 3, n. 1, p. 12-14, 1989.

LINGLE, S. E.; IRVINE, J. E. Sucrose synthase and natural ripening in sugarcane. Crop Science, v. 34, n. 5, p. 1279-1283, 1994.

LIU, D. L.; HEYLAR, K. R. Simulation of seasonal stalk water content and fresh weigh yield of sugarcane. Field Crops Research, v. 82, n. 1, p. 59-73, 2003.

LÓPEZ-MILÁN, E; PLÀ-ARAGONÉS, L. M. A decision support system to manage the supply chain of sugar cane. Annals of Operations Research, v. 219, n. 1, p. 285-297, 2014.

MENDIBURU, F. Package 'Agricolae': R package version 1.3-2. 2020. Available at: https://cran.r-project.org/web/ packages/agricolae/agricolae.pdf. Access on: 10 April 2020.

MOORE, P. H.; BOTHA, F. C.; FURBANK, R. T.; GROF, C. P. L. Potential for overcoming physio-biochemical limits of sucrose accumulation. In: KEATING, B. A.; WILSON, J. R. (ed.). Intensive sugarcane production: meeting the challenges beyond 2000. Oxon: CAB International, 1997. p. 141-155.

R DEVELOPMENT CORE TEAM. $R$ : a language and environment for statistical computing. Vienna: $\mathrm{R}$ Foundation for Statistical Computing, 2019.

ROBERTSON, M. J.; DONALDSON, R. A. Changes in the components of cane and sucrose yield in response to drying-off of sugarcane before harvest. Field Crops Research, v. 55, n. 3, p. 201-208, 1998.

SCARPARI, M. S.; BEAUCLAIR, E. G. F. Sugarcane maturity estimation through edaphic-climatic parameters. Scientia Agricola, v. 61, n. 5, p. 486-491, 2004.

VAN DILLEWIJN, C. Botany of sugarcane. London: Chronica Botanica, 1952.

VANHEERDEN, P. D.; EGGLESTON, G.;DONALDSON, R. A. Ripening and postharvest deterioration. In: MOORE, P. H.; BOTHA, F. C. (ed.). Sugarcane: physiology, biochemistry, and functional biology. New Delhi: John Wiley \& Sons, 2014. p. 55-84.

VILLEGAS, F. J. Maduración y crecimiento de la caña de azúcar. Carta Trimestral - Cenicaña, v. 32, n. 1-2, p. 47-54, 2010 . 